Éva Péteri

\title{
Tennyson and His Pre-Raphaelite Critics
}

\section{Pre-Raphaelite Interpretations of Tennyson's "The Lady of Shalott"1}

Literary paintings are like essays on literature. Intending or not, the painter inevitably interprets the words of a writer as he makes them visible. The analysis of a group of paintings illustrating the same literary work is like perusing a collection of critical studies on the same subject, produced, however, not by literary scholars or theorists, but by sensitive readers, fellow artists. Nevertheless, their approaches often show close affinities with well-known trends in literary criticism. Tennyson's mysterious "The Lady of Shalott," where several things remain unsaid and unexplained, allows a range of vindicable interpretations. No wonder, therefore, that it has always excited critics and painters alike, each of them being affected by their personal, literary, and historical experiences in forming and presenting their views.

At the same time a literary painting is the re-creation of what is given in the text. In addition, regarding the written work itself as the re-creation of reality, its visual rendition becomes re-recreation. In the case of simple visual images rereflection means the recovery of the original, of reality itself. But artistic recreation, either in words or in images, is not merely a mirrored presentation of reality. As a result of artistic selection and intensification ${ }^{2}$ it is also transformation, which means that the reflected image becomes distorted. Nevertheless, regarding re-reflection as the key to the understanding of

\footnotetext{
${ }^{1}$ The author's work was sponsored by the OTKA Postdoctoral Research Grant (D34578).

${ }^{2}$ Cf. Péter Egri. Value and Form: Comparative Literature, Painting and Music. Budapest: Nemzeti Tankönyvkiadó, 1993, pp. 30-36.
} 
Tennyson's "The Lady of Shalott," there is still some important parallel between the notion of double visual reflection in the poem and the duality of a literary painting. As reality intrudes upon the lady by her looking either at reality itself or, equally, at Lancelot's doubly reflected image in her mirror, her tapestry, her work of art disintegrates, her visionary world and source of inspiration is flawed by cracks. Based on analogy, the re-reflective quality of a literary painting may bring about the destruction of the magic visionary world of the poem. And, to a certain extent, it really happens to Tennyson's poem in its Pre-Raphaelite renditions. These painterly interpretations necessarily reduce the manifold meaning and mysterious nature of the poem to a final, thus much limited version of it.

Examining the Pre-Raphaelite painters' pictures inspired by the poem the present paper tries to disclose how these artists understood the story of Tennyson's cursed lady and how their approaches and treatments defined the poem and, in certain cases, altered its original character.

\section{TENNYSON}

"It is what I have always felt even from a boy," said Tennyson about one of his poems, "and what as a boy I called 'the passion of the past.' And so it is with me now; it is the distance that charms me in the landscape, the picture and the past, and not the immediate to-day in which I move." ${ }^{4}$

As part of his deep-rooted passion for the past Tennyson is reported to have announced his intention to rewrite the legend of King Arthur in the early 1830 s, willing to build on the renewed early 19 th-century interest in the saga, and supplement a modern reinterpretation of the ancient stories. ${ }^{5}$ The work engaged him for over sixty years, the first pieces being written in the early 1830s, and, as late as in 1891, a year before his death, Tennyson is said to have still been concerned with some work on the final version known as Idylls of the King. ${ }^{6}$

\footnotetext{
3 "Tears, Idle Tears" (1847).

${ }^{4}$ Quoted in Carr. "Tennyson as a Modern Poet." In: John Killham ed. Critical Essays on the Poetry of Tennyson. London: Routledge and Kegan Paul, 1960, p. 45.

${ }^{5}$ Debra N. Mancoff. The Return of King Arthur: The Legend through Victorian Eyes. New York: Abrams, 1995, p. 50.

${ }^{6}$ Mancoff, p. 51.
} 
Tennyson's long-lasting interest in the Arthurian legends reflects the general Victorian enthusiasm for them, and corresponds well with the great popularity of themes taken from them in contemporary art. In 1847 the legendary cycle of King Arthur and the knights of the Round Tabie was decided on as the most appropriate subject for the decoration of the newly built Palace of Westminster, and scenes from it, inspired either by the ancient accounts or by Tennyson's reinterpretations, featured in many celebrated paintings of the time produced by artists like Joseph Noel Paton, George Frederick Watts, Arthur Hacker, James Archer, and many of the Pre-Raphaelites.

At the time of the formation of the Pre-Raphaelite Brotherhood in 1848 and in the early years of their joint work their choice of subject was decisively influenced by their strong affection for literature; Shakespeare, Dante, Keats and Tennyson being their first favourites. Of the early members and associates William Holman Hunt, Dante Gabriel Rossetti, John Everett Millais and Elizabeth Siddal are all known to have had an especially great admiration for Tennyson's works, ${ }^{\prime}$ and, as Andrea Rose observes, the "lapidary, pictorial quality [of Tennyson's poetry] and its lush evocation of the medieval past" ${ }^{8}$ meant that it lent itself well to pictorial presentation. In addition, the Pre-Raphaelites became personally acquainted with Tennyson in 1849 , when the sculptor member of the brotherhood, Thomas Woolner was commissioned to make a medallion of the poet, and Tennyson began sitting for him.

Many of Tennyson's poems gave inspiration to early Pre-Raphaelite pictures. Mariana and St Agnes' Eve, for example, were the sources of Millais' works with the same titles made in 1851 and 1854, Siddal's Saint Cecily and the Angel (n.d.) was inspired by The Palace of Art and her Lady Clare (1854-7) by the poem Lady Clare, while Arthur Hughes' April Love (1855-56) was exhibited with a quotation from The Miller's Daughter. However, it was The Lady of Shalott which proved to provide the most lasting inspiration exerting its influence on the early Pre-Raphaelites in the middle of the $19^{\text {th }}$ century as well as on their late followers at the beginning of the $20^{\text {th }}$.

\footnotetext{
Cf. William Holman Hunt. Pre-Raphaelitism and the Pre-Raphaelite Brotherhood. London: Macmillan, 1905, Vol. I, pp. 316-7; Vol. II, p. 177; Oswald Doughty \& John Robert Wahl eds. Letters of Dante Gabriel Rossetti. Oxford: Clarendon Press, 1965-67, p. 1857; John Guille Millais. The Life and Letters of Sir John Everett Millais. London: Methuen and Co., 1905, pp. 67, 283; William Allingham. A Diary, 1824-1889. London: Penguin Books, 1985, p. 163; Alicia Craig Faxon. Dante Gabriel Rossetti. Oxford: Phaidon Press, 1989, p. 78.

${ }^{8}$ Andrea Rose. Pre-Raphaelite Portraits. Yeovil: Oxford Illustrated Press, 1981, p. 95.
} 
Though not exactly originating from the Arthurian legends, the story of Tennyson's The Lady of Shalott bears close resemblances to that of Elaine the White of Astolat, which is an essential part of the cycle. Nevertheless, Tennyson's immediate source is claimed to have been the Italian romance La Damigella di Scalot. ' The story, as related by Tennyson, tells how the lady, held by a miraculous spell, was working day and night on a tapestry depicting scenes of the outside world. Being inhibited from looking at the world directly, she viewed it through a mirror, until a day, when Sir Lancelot appeared in it, and the lady, defying the curse, turned around to have a look at him. In the same moment the mirror cracked and the tapestry disintegrated, signalling that the curse had been fulfilled. Leaving her lonely tower and the island of Shalott the lady sat into a boat, and, singing her last song, drifted down the river to her death. As the boat reached land at Camelot people gathered to have a look at the mysterious vessel and its lady. Lancelot was one of them, and his musing words on the lady's beautiful features close the poem.

In a contemporary article the poem was described as "a strange ballad, without a perceptible object" ${ }^{10}$ probably for its incompleteness, since, as Lionel Stevenson observes, ${ }^{11}$ it gives no explanation as to why a curse has been put on the lady, what the exact reason for her defiance is, or how her death is actually caused. Others, like R.H. Hutton regarded the poem as an allegory, claiming that "it has for its real subject the emptiness of the life of fancy ... which compels any true imaginative nature to break through the spell which entrances it in an unreal world of visionary joys." ${ }^{12}$ Taking his explanation further, Hutton adds, "[t]he curse is that she shall be involved in mortal passions, and suffer the fate of mortals, if she looks away from the shadow of reality." ${ }^{13}$ Stevenson also sees the poem as an allegory, according to him the lady of Shalott represents the artist, who, being completely isolated from the outside world, is "weaving beautiful pictures which are supposed to reproduce real life but which are derived entirely at second hand through the mirror." ${ }^{14} \mathrm{He}$ finds his interpretation just relevant to Tennyson's own retreat to an ivory tower, and to the fact that Tennyson's poetry

\footnotetext{
${ }^{9}$ Cf. Lionel Stevenson. "The 'High-Born Maiden' Symbol in Tennyson.” In Killham, p. 129, note 1.

${ }^{10}$ Quoted in Christopher Ricks. Tennyson. London: Macmillan, 1989, p. 73.

${ }^{11}$ See Killham, p. 129.

${ }^{12}$ Quoted in Ricks, p. 74.

${ }^{13}$ Quoted in Ricks, p. 74.

${ }^{14}$ Quoted in Killham, p. 130.
} 
of the time was often, and not without justifiable reasons, accused of being "artificial and derivative." 15

\section{TENNYSON'S CRITICS}

Interestingly, the early Pre-Raphaelite paintings were received with similar reserves. Overtly admitting their admiration, and, in a way, returning to the pictorial tradition of medieval and early Renaissance art, they incurred accusations of displaying "an unintelligent imitation of the mere technicalities of old art."16 However, as one of their main principles, the Pre-Raphaelites wished to avoid imitation of all kinds, willing to study nature directly and to take it as the basis of their presentations. Tennyson's concern with art and artistic creation naturally excited the novice painters; their similar concerns are reflected in Rossetti's search for an artistic creed in his short story Hand and Soul, and in Hunt's enthusiasm discovering the first volumes of Ruskin's Modern Painters finding its moral approach to art a principle he could whole-heartedly take on.

\subsection{Allegorical approach: the lady as the failing artist}

The earliest Pre-Raphaelite picture inspired by Tennyson's The Lady of Shalott was made by William Holman Hunt in 1850, at the same time when Millais started working on Mariana. Hunt's fascination with the poem was so strong that he concerned himself with it till the end of his life, producing altogether four different versions, on the course of which he developed his early drawing into the magnificent oil painted between 1886-1905. The four versions; the drawing of 1850 [Fig. 1], an illustration made for Edward Moxon's edition of Tennyson's Poems in 1857 [Fig. 2], a water-colour painted between 1889-92 [Fig. 3], and the oil completed only a few years before the painter's death [Fig. 4], are all based on the same design, which reflects that Hunt's view of the poem and the reason for his attraction to it had remained unaltered throughout the long years he was concerned with it. In all the versions he shows the decisive moment of the lady's defiance of her fate to live in a world of reflections; her fatal turn to the window and to the forbidden outside world.

\footnotetext{
${ }^{15}$ Quoted in Killham, p. 130.

${ }^{16}$ Cf. Francis Bickley. The Pre-Raphaelite Comedy. London: Constable and Co., 1932, p. 176.
} 
In accordance with the poetic narrative Hunt presented the lady's incomplete tapestry disintegrating, and showed the figure of Lancelot being reflected in the cracked, circular mirror in the background. However, quite atypically of his usual accuracy, he depicted the lady as being entangled in the flying threads of her decomposing work, which is obviously contrary to what Tennyson had described in his poem ("She left the web, she left the loom/She made three paces thro' the room..."). When the poet saw Hunt's illustration made for the Moxon edition, he complained about the freedom Hunt had allowed himself in his rendition of the scene, but the painter answered, defending his concept, that he "had only a half page on which to convey the impression of weird fate, whereas [Tennyson] use[d] about fifteen pages to give expression to the complete idea." ${ }^{17}$ As Hunt's comment suggests, he wanted to seize the moral essence of the poem, and not just to present one of its incidents. Thus, in order to convey the "complete idea" he tried, at first, to retain something of the narrative sequence of the poem by enhancing the natural boundaries of pictorial presentation and presenting pictures within the picture. In the drawing made in 1850 eight small roundels, depicting the most important preceding and future moments of the lady's story, are placed around the huge circular mirror in the background, which, if read clockwise, starting from the top, relate the complete story. The first roundel shows the view of Camelot, the second the lady working on her loom, the third her catching sight of the "young lovers lately wed" in the mirror, and the fourth the image of Sir Lancelot riding by. The fifth roundel is obscured by the figure of the lady, but it can be considered as identical with the drawing itself, presenting the climatic moment of the story, the fulfilment of the curse. The last three roundels are all shown as cracked, as they foretell events to come; the lady's writing her name on the prow of the boat, then the boat drifting down the river, and finally the boat reaching land at Camelot.

Hunt's wish to recapitulate the narrative of Tennyson's poem in this early drawing reflects the Pre-Raphaelites' early strong reliance on narrativity. Actually, narrativity was peculiar not just to early Pre-Raphaelite art but to mid-Victorian painting in general. The Victorians were eager to find a narrative aspect in a painting, they expected it to tell a story and were ready to invent their own if there was no direct reference in the title or in the exhibition catalogue. They were so accustomed to having a narrative interpretation that in the $1860 \mathrm{~s}$, when the first works of purely aesthetic nature were beginning to appear on the walls of

${ }^{17}$ Hunt, Vol. II, p. 125. 
exhibition halls they had difficulty interpreting them. ${ }^{18}$ Literary themes were in general popular, since then the narrative content, the 'explanation' was already at hand in the written work. There were two common ways to give narrative dimension to a painting, which is bound by its nature in time and space. The most obvious solution was to paint a series, the tradition of which goes back in England to the famous sequences of Hogarth and finds its 19th-century exponents in such famous works as William Powell Frith's The Road to Ruin (1878) and Augustus Egg's Past and Present (1858). This type was mostly relied on in the case of what Hogarth called "modern moral subjects" 19 where, unlike in the case of literary paintings, there was no pre-formulated story to support the visual rendition, and thus everything had to be 'told' by visual means. The other way was the application of symbolic references, which, though made the spectators' task of 'reading' the painting more demanding, allowed the painter to concentrate more on the main scene, thus the picture could become more powerful, emotionally more effective.

The purpose of Victorian narrative painting was definitely didactic: it wanted to teach, to present a moral lesson. It was John Ruskin, whose theories on art influenced perhaps the most the mid-19th-century concepts of painting and architecture. He was an ardent advocate of the moral responsibility of the artist, identifying the artist's role with that of a priest. It was also Ruskin, who tried to re-establish the former rank and common knowledge of typological symbolism in art. Analysing Tintoret's The Annunciation in the second volume of Modern Painters he shows how the meaning, the message of a painting can be extended by giving it a "typical [typological] character." ${ }^{20}$ As it has already been mentioned Hunt's artistic creed was much influenced by Ruskin and the Ruskinian moral concerns. His wish to convey a moral message and his general reliance on some sort of narrative make Hunt's works typically mid-Victorian. But whereas for his early drawing of The Lady of Shalott he chose the more conventional sequential type, in his later renditions of the poem he concentrates on just one incident and gives extension to it by using symbolic references.

By the time Hunt was working on the illustration for Moxon's Tennyson he tried to lay the emphasis only on the dramatic power of the depicted moment

\footnotetext{
${ }^{18}$ Cf. Russell Ash. Sir Edward Burne-Jones. New York: Abrams, 1993, Plate 19.

${ }^{19}$ In Simon Wilson. British Art: from Holbein to the Present Day. London: The Tate Gallery \& The Bodley Head, 1979, p. 30.

${ }^{20}$ John Ruskin. Modern Painters. London: André Deutsch Lim., 1989, pp. 259-60.
} 
itself, on the sudden action and the immediate reaction; the lady's rebellion and the instantaneous fulfilment of the curse. Thus he made the clasp of the threads on the lady's body stronger, and presented the lady with a twisting body and windblown hair. Tennyson, again, protested, claiming that he had never said that the lady's hair was "wildly tossed about as if by a tornado" and that "the web [wound] round and round her like the threads of a cocoon."

Tennyson was of the opinion that the illustrations should have been subordinated to the text and should remain faithful to it overall. Typical of his insistence on such pictorial accuracy, he criticised Millais for painting daffodils along with wild-roses in Ophelia back in 1852. Millais simply "wanted a bit of a yellow" in the painting, but Tennyson told him that "it was quite wrong," 22 since daffodils could not possibly bloom in the summer, when wild-roses do, and Millais, feeling quite embarrassed, quickly painted them out. However, neither Hunt nor, as it will be seen later on, Rossetti was as compliant as Millais. Thus, despite Tennyson's disapproval, their illustrations made for Moxon were published unaltered, constituting far more independent renditions of the poems than any of the rest of the volume.

When Hunt returned to the theme of the lady of Shalott in the 1880s his concept was even more alienated from the Tennysonian text. The swirling movement became more emphatic, and the lady's attempt to free herself from the entwining threads more desperate. In addition, both the watercolour and the oil versions were extensively amplified with elaborately painted details, none of which has anything to do with the narrative of the poem itself. By this time such detailed elaboration and heavy reliance on prefigurative symbolism had become distinctive features of Hunt's paintings in general. The symbols were basically due to extend the scope of the depicted incident by bearing references to past and future events as well as extending the moral or spiritual aspects of the story. Their application in The Lady of Shalott was Hunt's new, and probably more successful attempt "to give expression to the complete idea" of the poem.

As Landow observes, compared to most of Hunt's other paintings like The Finding of the Saviour in the Temple, The Scapegoat, or The Awakening Conscience, the symbols he employed in the late versions of his The Lady of Shalott "do not serve as the generating force," they only "comment upon the main

\footnotetext{
${ }^{21}$ Hunt, Vol. II, p. 124.

${ }^{22}$ Quoted in Allingham, p. 379.
} 
theme." ${ }^{23}$ The relatively loose connection between the symbols and the main theme is also indicated by the fact that most of them are distinct in the different versions. The decoration on the background wall, for example, is unique to each version. In the Moxon illustration it shows the Crucifixion, which may refer to artistic self-sacrifice. In the water-colour it presents the enthroned Lord holding a sphere and being surrounded by winged angel-heads, which is a traditional way of presenting the Creation, and which is probably due to refer to the lady's artistic, creative type of work. In accordance with it the upper section of the wall depicts cherubs, each of whom, strangely enough, seems to be engaged in some sort of creative activity, either physical or artistic. One of them is shown carrying containers, another digging, a third spinning, while one is playing the flute and another the cello. Hunt's presentation of such duality of creative work may have originated in Carlyle's description of honourable workers in Sartor Resartus as the toiling craftsman and the inspired thinker or the artist, which also inspired the concept of Ford Madox Brown's painting Work (1852-65).

The background of the oil version of Hunt's The Lady of Shalott presents Hercules in the garden of the Hesperides on the right, and the Nativity on the left, while celestial bodies are shown in the upper part. Hercules - who is a common prefiguration of Christ - performing his twelve labours fought heroically against evil, and, as a reward, gained remission of his sins and was granted immortality. Christopher Wood claims that Hunt "intended [his painting] as an elaborate fable representing the conflict between the forces of good and evil," ${ }^{24}$ which corresponds well with the same concerns in the story of Hercules, and the same in that of Christ. At the same time, the figures representing the celestial bodies may stand for the unknown forces of fate, the turns of which is incomprehensible and immutable.

The tapestry the lady had been working on is partly visible in both paintings, and in both of them it seems to depict Sir Galahad's attainment of the Holy Grail. Here again Hunt deviated from the text of the poem, since according to the text the tapestry was due to reflect the outside world as it had been revealed to the lady in the mirror. The mystic appearance of the Holy Grail in Hunt's paintings suggests that the tapestry is endowed with a symbolic significance by the painter, standing not just for the object of the honest work of the artist, but also

${ }^{23}$ George P. Landow. William Holman Hunt and Typological Symbolism. New Haven: YUP, 1979, p. 139.

${ }^{24}$ Christopher Wood. The Pre-Raphaelites. London: Wiedenfeld and Nicholson, 1983, p. 109. 
for an achievement which reaches beyond human capacity. The symbolic decorations on the stands of the loom and the candlestick placed inside it, presenting water, earth, air and fire, may also refer to an ideal entirety and perfection, the ultimate end of all honest work of art. Had it been completed, the tapestry would have filled the space on the wall now occupied by the mirror, the legend of the attainment of the Holy Grail, in which Celtic and Christian elements are combined, giving a matching counterpart to the Christian Nativity scene, and the story of Hercules of Greek mythology, in the sense that they all represent the manifestation of divine grace.

At the same time the moment represented in the painting is that of the disintegration of the tapestry, thus it implies that the lady has failed to accomplish what she was entrusted with by rebelling against her appointed duty. The picture shows, as Landow describes, a "powerful moment of illumination," 25 the moment when the devastating consequences of one's failure become suddenly manifest. The loss of divine grace is also indicated by the presentation of the doves, since, unlike their heavy presence in the Nativity panel in the background, as soon as they appear on the right in the painting, they immediately depart through the opening at the top. In Peter Betthausen's opinion the universal message Hunt wished to deliver in this painting was that the essence of things can never be known to any human being, which may imply that the lady's failure and the consequent loss of divine grace were inevitable. ${ }^{26}$

Betthausen also suggests ${ }^{27}$ that Hunt may have intended to reflect on the restricted social role of the women of his time, and on the enclosed domestic world they were confined to live in. Landow, however, makes a definite distinction between those works of Tennyson and the Pre-Raphaelites on the one hand, which, as he describes, present "the woman inside," and The Lady of Shalott, Tennyson's poem and Hunt's paintings on the other. As he explains, though Tennyson as well as the Pre-Raphaelites "frequently portrayed single figures of women within an enclosed space or room which embodies their psychological and moral condition [...] Hunt's The Lady of Shalott and its Tennysonian original employ this device to represent allegorical or mythic figures who are not literal women but aspects of humanity as a whole., ${ }^{28}$

\footnotetext{
${ }^{25}$ Landow. Hunt and Typological Symbolism, p. 20

${ }^{26}$ Peter Betthausen. Die Präraffaeliten. Berlin: Henschelverlag Kunst Gesellschaft, 1989, nr. 60.

${ }^{27}$ Betthausen, nr. 60 .

${ }^{28}$ Landow. Hunt and Typological Symbolism, p. 46.
} 
Hunt's unwavering adherence to his youthful artistic creed to the end of his life shows how much convinced he was of the propriety of his chosen way. His typically mid-Victorian moralism extended into the $20^{\text {th }}$ century, by which time it was regarded by most as long and clearly outdated. By that time Hunt's morally charged 'symbolic realism', as Landow terms Hunt's approach, ${ }^{29}$ got new dimensions and found its successors in the imaginative symbolism of George Frederick Watts and the highly decorative symbolic Art Nouveau style of Edward Reginald Frampton.

\subsection{Feminist approach: the lady as a woman}

Given the poem's own reliance on the division between the enclosed, isolated world of the lady and the open, public world of Lancelot, the pictures inspired by the poem are often seen as being concerned with a similar dichotomy so typical of the Victorian era. As it has already been referred to, even Hunt's work is considered to reflect upon this theme. In the case of Elizabeth Siddal's drawing, however, it is almost indispensable, since the fact that it was made by a woman artist makes such an approach too enticing. Elizabeth Siddal, the model of many famous Pre-Raphaelite paintings and later the wife of Rossetti, is a favourite choice for feminist studies where the authors are attempting to view her artistic role and place within the Pre-Raphaelite circle independent of male oriented approaches and categories. But even without setting such a far-reaching feminist aim, it is interesting in itself to examine whether a woman artist treated the subject of The Lady of Shalott differently than her male companions or not.

What is most striking in Siddal's drawing [Fig. 5] is the relative plainness of the setting and the figure alike. Despite the tapestry hanging on the background wall and the carved decorations on the Lady's chair and the chest in front of the window, the place looks bare and does not at all recall the medieval atmosphere of the poem. Furthermore, Siddal's Lady is quite ordinary and far the least feminine of all her Pre-Raphaelite presentations. It may be the result of the artist's feminine approach, which implies the refusal of the masculine one according to which, as Griselda Pollock puts it, "the feminine [the woman] is

${ }^{29}$ George P. Landow. Victorian Types Victorian Shadows: Biblical Typology in Victorian Literature, Art, and Thought. London: Routledge \& Kegan Paul, 1980, p. 123. 
positioned as the object of the look." ${ }^{30}$ In Siddal's drawing, as Deborah Cherry observes, "The Lady is represented at the moment of ber look. She is not offered as a victim or a spectacle for the masculine gaze." ${ }^{31}$ It must be remembered, however, that the poem itself is about her look and her view of reality in general. Thus the basic question is, in this context, whether it has a significance at all that the story is concentrated on a woman figure. As it has already been referred to, in Landow's opinion Hunt's Lady stands for all humanity and in this sense her femininity plays no part in the meaning of her story. Nevertheless, Hunt's presentation of the Lady shows an unusual sensuality - unusual in Hunt's case -, thus, in this sense, even Hunt's approach can be regarded as typically masculine. At the same time, Siddal's Lady, her plainness, her complete lack of sensuality, maybe even unattractiveness, suggest a more feminine treatment.

Describing Siddal's drawing Deborah Cherry claims that it reflects upon the mid-19th-century concern with gender difference in the sense that it "produces and reproduces the ideology of the separate spheres of men and women, and in its representation of an historical past it works over contemporary distinctions between the private indoor world of women and the public, outdoor world of men." ${ }^{\$ 2}$ The Victorians are, indeed, noted for their observance of clear-cut roles for women and men. It is actually Tennyson whose lines in The Princess are often quoted to illustrate this polarity:

Man for the Field and Woman for the Hearth:

Man for the Sword and for the Needle She:

Man with the Head and Woman with the Heart:

Men to command and Woman to obey;

All else confusion.

Using capital letters in the key nouns of the text Tennyson gives emphasis to those things and qualities which are most strongly associated with the feminine and the masculine roles endowing attributes on the types as it is done in allegorical painting. Thus the 'Woman' is identified with the Hearth, the Heart and the Needle, which imply her restrictive domesticity, the notion that she belongs to the home and to the family, and that she should occupy herself in

${ }^{30}$ Griselda Pollock. Vision \& Difference: Femininity, Feminism and the History of Art. London: Routledge, 1988, p. 114.

${ }^{31}$ Deborah Cherry. The Pre-Raphaelites. London: Tate Gallery, 1984, p. 266.

${ }^{32}$ Cherry, p. 266. 
conformity with her role and space. In accordance with Tennyson's lines women are most often depicted as mothers, as wives doing needlework in Victorian painting. Ford Madox Brown's Waiting: An English Fireside (1855) or Charles West Hope's A Life Well Spent (1862) are just a few of the many examples. Weaving a tapestry the Lady of Shalott can, then, be seen as belonging to this tradition, though weaving may demand more power and creativity, thus can be regarded as more masculine according to Victorian standards. At the same time, the Lady as a lonely woman is completely out of her role, she has no husband to guide and defend her, and no children to be looked after which would make her mind and hands 'properly' engaged. In Victorian terms remaining single and solitary was, for a woman a curse in itself. Furthermore, the Victorian consciousness knew only two basic types of women: the virtuous, even saintly but asexual wife, and the sensuous, impure mistress or whore; the Virgin Mary and the Magdalene types. Not belonging to one almost meant belonging to the other. Thus the Lady of Shalott, living isolated, without proper male guidance and control, is, at least suspicious of being rather a Magdalene, and the overt sensuality of most of the visual presentations, where instead of being a helpless victim the Lady is depicted as a femme fatale type, seem to build upon this idea. Siddal's drawing, however, definitely denies this aspect. Presenting the Lady as calm, serene, and unsensuous she makes her pure and self-controlled.

All these 'feminine' characteristics in Siddal's work notwithstanding, the details of the drawing do not seem to indicate a distinction between the "private indoor world of women and the public outdoor world of men." ${ }^{33}$ On the contrary, many features, which are unique to Siddal's concept, seem to make the contrast between the lady's lonely and home-ridden world and the free, public life of the knights of Camelot even less prominent than it is in the poem. One of them is the type of the presented chamber itself, which is spacious, light, and airy, its huge window allowing a wide view of the outside world. The ivy, climbing up on the window frame connects the chamber directly with the outside world, just like the singing bird on the top of the frame of the loom, none of which is actually mentioned in the poem. Describing the poem Cherry writes that the bird is shown just having perched on the tapestry; however, as the lines of the drawing may suggest, it is perhaps tied to it, which may be regarded as the only indication of the lady's captive life. ${ }^{34}$ On the other hand, Lancelot, who is supposed to

${ }^{33}$ Cherry, p. 266.

${ }^{34}$ Cherry, p. 266. 
represent the "public outdoor world of men," appears solitary in the cracked mirror, emerging as a ghost or a faint vision, as nothing of the outside world that should surround him is reflected in the mirror. Like the bird, the crucifix on the chest is Siddal's own addition, which, according to Faxon, "may signify the sacrifice of the artist in creating a work of art." ${ }^{35}$ Cherry also finds that the lady's work is an important aspect of the drawing. She describes the chamber as a "work-room," and refers to the tapestry in the background as the indication of the lady's past labours. ${ }^{36}$ Nevertheless, the lady's occupation of weaving is not emphasised, her chest is empty, and there are no balls of wool around to work with.

Though her tapestry disintegrates and the mirror cracks, the lady remains surprisingly calm, not seeming to realise the tragic consequences of her act of defiance, or bother about the fulfilment of the curse. In Cherry's view "Siddal's drawing refuses the narrative drive of the poem" in the sense that it "resists the ending in death." ${ }^{37}$ At the same time, it means, that the incident as shown by Siddal lacks the dramatic power of both the relevant section of the poem and Hunt's interpretations of it. It can be argued whether it was Siddal's intention to undramatise this highly tense and climactic scene of the poem or it was just her inability to capture the fatality of the depicted moment which made her work so peculiar. Scholars are much divided in their estimates, some like Jan Marsh or Alicia Craig Faxon emphasise the ingenuity of her work and claim Siddal a prominent and independent role in the history of Victorian art, ${ }^{38}$ others, like Christopher Wood believe that her works "show little original talent." 39

\footnotetext{
${ }^{35}$ Faxon, p. 79.

${ }^{36}$ Cherry, p. 266.

${ }^{37}$ Cherry, p. 266.

${ }^{38}$ Cf. Faxon, pp. 81-83; Jan Marsh. Pre-Raphaelite Women: Images of Femininity in Pre-Raphaelite Art. London: Wiedenfeld and Nicholson, 1987, pp. 72, 110. See also the brief review of Siddal's work in the exhibition guide of "Elizabeth Siddal: Pre-Raphaelite Artist 1829-1862" (26 January to 13 April 1991, Ruskin Gallery, Sheffield), which, strangely enough, finds her drawings and watercolours, The Lady of Shalott among them, "emotionally [...] intense and dramatic, often depicting moments of crisis."

${ }^{39}$ Christopher Wood. Victorian Painting. London: Wiedenfeld \& Nicholson, 1999, p. 325.
} 


\subsection{Reader-response approach: the lady as the dead lover}

Originally Hunt was to make two illustrations to The Lady of Shalott for Moxon's Tennyson, but Rossetti begged one of them from him, being strongly attracted to the medieval and mystic aspects of the story. Rossetti's view of the function of an illustration was definitely distinct from that of Tennyson; he was ready to pay attention "not to kill the distinct idea of the poet," but he basically wanted to "allegorise on [his] own hook on the subject." ${ }^{40}$ As in reader-response criticism the literary text is regarded as of secondary importance compared to his own feelings and impressions of it.

Accordingly, when making his illustration to the poem [Fig. 6], he put Tennyson's text aside without scruples, and searched for the earliest record of the story he could find. His final detection was Lancelot $d u$ Lac, the early $14^{\text {th }}$-century French manuscripts in the British Museum, which contain several miniatures relating the legend of Lancelot. One of them depicts the same incident as the one presented by Rossetti, showing Lancelot musing over the beautiful dead lady, whose boat has been drifted ashore at Camelot. Both the miniature and Rossetti's drawing depict the knight leaning over the boat in order to see the lady it carries, and each presents a group of curious onlookers gathering behind him. As in all of Rossetti's drawings and water-colours inspired by medieval art the image he created is crowded and over-all detailed, which, though much angering the engravers, who found it impossible to render satisfyingly in a wood-cut, corresponds well with the teeming and excitement suggested in the poem.

Besides the opportunity of being immersed in a medieval subject, Rossetti was most probably also attracted by the theme of the depicted scene itself. Emotionally charged, dramatic encounters of men and women as well as the conflict of the dead and living have always fascinated him, as is revealed by such works as The Raven (1847), The Blessed Damozel (poem: 1847, painting: 1875-78), Arthur's Tomb (1855), The Salutation of Beatrice (1859) or How They Met Themselves (1851-60). The way Lancelot is shown gazing at the beautiful, dead lady in this drawing clearly foreshadows his famous presentation of Dante gazing at his dead Beatrice in Dante's Dream at the Time of the Death of Beatrice (water-colour: 1856, oil: 1871).

As an interesting thematic counterpart of Siddal's work, which shows the solitary woman looking at the ghostly appearance of an armed man, Rossetti's

${ }^{40}$ Doughty \& Wahl, p. 239. 
drawing depicts a man of bustling society looking at the ghostly appearance of a beautiful woman in a death-barge. If Siddal's version presents her look, than Rossetti's one definitely depicts his look, which is eager, tense, remorseful yet devouring. The burning candles and the fire of the torches intensify the 'heat' of the moment, which is counter-balanced by the cool water, the calm and graceful swans and the busy, unconcerned folks in the background. The presentation of a passive, beautiful female figure being exposed to the adoring gaze of a perplexed man in Rossetti's drawing foreshadows the concept of some of Burne-Jones' compositions, the "Pygmalion" Series (1868-1870), the whole story of which is about the sculptor Pygmalion's devotion to the ideal beauty of his creation Galathea; King Cophetua and the Beggar Maid (1884), in which the sovereign is shown worshipping the simple yet so mysterious maiden; and all the "Sleeping Beauty" pictures, where the unconscious princess lies unaware of being approached. Also, though in a more remote way, it anticipates Frederick Leighton's and Albert Moore's reposing and sleeping female beauties as well as Rossetti's female portraits where the static, apparently unaware women characters remain the same, just the admiring male figure is eliminated his role being taken over by the spectator himself.

In Rossetti's pictorial rendition of The Lady of Shalott the role of the Lady is much restricted, her fate, her rebellion become irrelevant, but she gains significance in her inert beauty and obscurity. Thus Rossetti's work points the way to an aesthetic approach, which tends to neglect the narrative background and concentrates on the presentation of aesthetic qualities.

\subsection{Aesthetic approach}

\subsubsection{Millais' elegy}

Of the Pre-Raphaelites it was Millais who contributed the most to Moxon's Tennyson, making altogether 18 illustrations, as compared to Hunt's eight, and Rossetti's five drawings. His study on Tennyson's The Lady of Shalott [Fig. 7] is also said to have been made as a design for Moxon's edition, however, it was never worked out as a proper drawing for an engraving. It depicts the lady floating down the river to Camelot, lying in her boat weak and powerless, resignedly awaiting the curse to be fulfilled on her. Her hands are reaching down into the water, while she is singing her last song. The river scenery with the inclining boughs of a willow in the background, the pose of the lady, and the 
theme itself are much reminiscent of Millais' celebrated Ophelia completed just two years earlier. The swans, not mentioned in the poem, appear first in this drawing, since Rossetti's work was made somewhat later. Millais' own account of his work on the landscape of Ophelia reveals that he had a memorable encounter with swans at the time, ${ }^{41}$ so the idea to have swans included in a similar scenery might have come from this earlier experience. But the swans may also carry a symbolic reference to death, as they are known to have a presentiment of their impending death and sing their last song, as, according to the poem as well as in the painting, does the Lady of Shalott. Lamenting the death of the Lady, Millais' rendition gives a pictorial elegy.

Analysing Millais's Ophelia Péter Egri observes that the Shakespearean tragic death of the literary Ophelia is transformed in the painting into a decorative death of a beautiful woman. ${ }^{42} \mathrm{He}$ uses the term "pre-Art Nouveau decorativity" to describe the basic quality of the picture finding its elaborate execution of delicate details - such as the colourful flowers and Ophelia's embroidered ancient dress - and its detachment from the dramatic source the most important elements of Millais's visual concept. And though it would be too daring to apply the same term in the case of the unfinished, very sketchy presentation of The Lady of Shalott its concentration on the harmony of the landscape and the figure instead of the dramatic or moral element of the story is a definite early mark of a departure from the Ruskinian-Huntian didactic moralism.

The reason for the fact that Millais never executed this study in a more complete form may be found in the design's lack of originality in the sense that it has such a close affinity with Ophelia, but the fact that in the middle of the 1850s Millais was already turning away from the strict narrativity of the early PreRaphaelite style may have also contributed to it. He started painting melancholic, mostly non-narrative pictures such as The Blind Girl (1854-56), Autumn Leaves (1855-56), Waiting (1854), or The Vale of Rest (1858), which remained favoured by him till the end of his life.

\subsubsection{Grimshaw's fairy-tale}

From the middle of the 1850 s the Pre-Raphaelites' early strong reliance on poetic subjects was generally weakening. While Millais turned to sentimental themes,

\footnotetext{
${ }^{41}$ Cf. Wood. The Pre-Raphaelites, p. 97.

${ }^{42}$ Péter Egri. "A preraffaeliták Shakespeare-képe." Holmi 3 (2000) 310-329, p. 324.
} 
Hunt devoted himself mostly to religious subjects, and Rossetti took to painting decorative portraits of beautiful women. At the same time, the legend of King Arthur was a great favourite with the artists of the second generation of the PreRaphaelite movement, such as William Morris, Edward Burne-Jones, or Frederick Sandys, but they found inspiration rather in Malory's Morte d'Arthur than in Tennyson's Victorian reinterpretation of it. And, as the story of the Lady of Shalott is not included in Malory, the subject lost its earlier popularity.

However, by the end of the century a new upheaval followed, many of the late Pre-Raphaelite followers rediscovering the poetic sources of their predecessors. As Christopher Wood observes, Tennyson's The Lady of Shalott was "almost a cult subject among the later Pre-Raphaelites." John Atkinson Grimshaw, John William Waterhouse, and Sidney Harold Meteyard are all noted. for their admiration for the poetry of Tennyson, ${ }^{44}$ and each of them took up The Lady of Shalott as his subject at least once.

Grimshaw was a self-taught artist from Leeds who, abandoning his job as a railway-clerk started painting landscapes in the Pre-Raphaelite manner in the 1860s. Gradually gaining fame in his local area he turned to literary themes. Nevertheless, his pictures inspired by literature are quite independent from their narrative sources. As Alexander Robertson observes when "he takes a line from a poem, Grimshaw gives us the feel of the words, the sense of time, the atmosphere - not merely an illustration of them. ${ }^{45}$ And, apart from a few domestic pictures, all Grimshaw's works - landscapes, townscapes, and literary works alike - suggest his complete immersion in the overwhelming atmospheric power of the mysteries of dusk and the evening lights, which shroud his imaginary lanes and Jacobean mansions in magic and make his rainy, muddy streets sparkle with golden gleam. Familiar reality at first sight, but made mysterious and alluringly beautiful.

The scene chosen but never fully carried out by Millais in his The Lady of Shalott was taken up again by Grimshaw some twenty years later [Fig. 8]. Though it depicts the same incident as Millais' drawing, Grimshaw's presentation is very different from that of his predecessor, and quite unlike Millais' early work in general. It evokes a visionary, fairy-tale world, depicting a dark, dragon-headed

\footnotetext{
${ }^{43}$ Wood. The Pre-Raphaelites, p. 139.

${ }^{44}$ Wood. Victorian Painting, pp. 168, 172; Anthony Hobson. Jobn William Waterhouse. London: Phaidon Press, 2000, p. 40; Alexander Robertson. Atkinson Grimshaw. London: Phaidon Press, 2000, pp. 58-9.

Robertson, p. 86
} 
funeral barge drifting alone with its lifeless passenger, dressed in gleaming white, towards the distant, misty towers of Camelot. The sky and the water are glowing in red and yellow as the sun is setting, where the ghostly vessel appears as an eerie apparition. As Leighton, Alma-Tadema, and Poynter, constituting the Classical Revival, created their idealistic visions of antiquity imbued with beauty, ease and harmony, so did Grimshaw invent his own world of enchantment, a world of mysterious stillness and quietude. All these realms can be regarded as the manifestations of the artists' resistance of the materialistic concerns of their busy age and accelerating rhythm of life.

Though starting as a landscapist in the Pre-Raphaclite manner Grimshaw, like Rossetti, gradually abandoned these early principles and became more and more attached to acstheticism, reading and appreciating Whistler rather than the 'old master', Ruskin. Family accounts suggest that Grimshaw knew Whister personally, and it seems that Whistler much appreciated what Grimshaw was doing. "I thought I had invented the Nocturne," Whistler is reported to have said, "until I saw Grimmy's moonlights." obviously more detailed, more discernible than those of Whistler, it is Grimshaw who could more successfully recreate the "fairy-land" described in the famous passage of Whistler's Ten O'Clock Lecturc, the section which is marked in the copy he owned:

And when the evening mist clothes the riverside with poetry, as with a veil, and the poor buildings lose themselves in the dim sky, and the tall chimneys become campanili, and the warchouses are palaces in the night, and the whole city hangs in the heavens, and fairy-land is before us than the wayfarer hastens home; the working man and the cultured one, the wise man and the one of pleasure, cease to understand, as they have ceased to see, and Nature, who, for once, has sung in tune, sings her exquisite song to the artist alone, her son and master - her son in that he loves her, her master in that he knows her. ${ }^{48}$

To Whistler, as well as to Grimshaw, Nature is admirable for its enchanting beauty in itself. This Nature is obviously different from the Ruskinian

\footnotetext{
${ }^{46}$ Robertson, p. 118.

${ }^{47}$ Robertson, p. 75.

${ }^{4 x}$ Robertson, p. 118.
} 
one which is charged with moral significance and is seen as the manifestation of divine perfection.

\subsubsection{Waterhouse's romances}

In a way similar to Grimshaw Waterhouse also created an imaginary world of his own. But whereas Grimshaw depicts a basically eventless, veiled and misty realm where the people appear like shadows or cut-out puppet-like figures drifting without any perceptible purpose, Waterhouse always tells a tale and always presents flesh and blood figures in highly realistic surroundings. In his work, as Christopher Wood describes, "the aestheticism of Burne-Jones and the classicism of Leighton are fused, producing yet another highly individual and romantic style."

Compared to Grimshaw's apparently superficial fascination with Tennyson's The Lady of Shalott, Waterhouse seems to have been more profoundly interested in the poem. His enthusiasm was actually so strong that he produced three different versions, each of which depicts a different incident of the poem. His early works being mostly influenced by the classical ideal, Waterhouse was won over to Pre-Raphaelitism probably after his visit to Millais' retrospective exhibition held at the Grosvenor Gallery in 1886, which he is known to have admired. ${ }^{51}$ His first painting produced in the Pre-Raphaelite style is said to have been his first The Lady of Shalott painted in $1888,{ }^{52}$ in which, as Hobson observes, he "moves from history to romance; and also, for a brief period, to plein-air painting."

The first picture [Fig. 9] presents the lady unchaining her boat and embarking on her final journey on the river to meet her fate on the way to Camelot. As compared to Grimshaw's rendition, the most important difference is that, while Grimshaw presented an imaginary, mythical realm, Waterhouse depicted a very real, willow-girded riverbank, reproducing the lady's mysterious story in a highly realistic manner. As Hobson describes, looking at the picture "one feels the cool of the day," which is suggested by the darkened sky, and by

\footnotetext{
${ }^{49}$ Cf. Ruskin, p. 200.

${ }^{50}$ Wood. Victorian Painting, p. 236.

${ }^{51}$ Cf. Wood. The Pre-Raphaelites, p. 141.

${ }^{52} \mathrm{Cf}$. Wood. The Pre-Raphaelites, p. 141.

${ }^{53}$ Hobson, p. 40.

${ }^{54}$ Hobson, p. 41.
} 
the indication of the breeze which lightly blows the lady's hair and the faint light of the candle. But, as Hobson continues, "the centre scene is held by the haunting beauty of the figure," ${ }^{55}$ whose expression recalls that of the dying Ophelia in Millais' early work.

To a certain extent the symbolism of the early Pre-Raphaelite works is also evoked by Waterhouse in this painting, though he rarely relied on such didactic means. The crucifix, the rosary and the candles, which are placed on the prow of the boat, are not mentioned in the poem, and their presence there can hardly be explained in view of the depicted scene itself. It is still light enough to have no need for candles, so the fact that the lady put them, as well as the crucifix, into the boat must imply that - in Waterhouse's understanding of the poem - the Lady is much aware of her fate and her nearing death. Thus with the application of these objects she has transformed her boat into a funeral barge something similar to Rossetti's coffin-like boat with its burning candles. Accordingly, the Lady's facial expression and slightly knit brows reflect painful resignation. The Lady's coming death is also referred to by the fact that only one of the candles is burning, and even that is mercilessly exposed to the blowing wind, as the Lady is exposed to forces beyond her power. Though in theme, in mood, and to some extent in symbolism the painting owes a lot to the early Pre-Raphaelite works, in style it does not follow them but shows affinities rather with the style of BastienLapage and the French 'plein-air' painters and their English followers, the painters of the Newlyn School.

The second painting Waterhouse made on the poem [Fig. 10], which depicts the climactic moment of the story, bears some resemblances to Hunt's works on the theme, despite the fact that, as Hobson suggests, Waterhouse made "an unusual number of preliminary sketches" probably for wishing "to avoid duplicating the composition" of Hunt's works. ${ }^{56}$ Comparing the two presentations Hobson argues for the originality of Waterhouse's composition, and in the final analysis finds it more impressive than that of Hunt. He claims that "Holman Hunt is seduced by a concentration on detail which fatally weakens his narrative power. The carefully contrived tonal balance completely misses the point; it thrusts the mirror forward at the very moment when its importance has been eliminated, and at the climax of the Lady's existence she is thrown into the shadows. Hunt delivers the final blows to the text by confining her within the

\footnotetext{
${ }^{55}$ Hobson, p. 41.

${ }^{56}$ Hobson, p. 53.
} 
low embroidery frame where it must have been agony to work day after day a few inches from the floor and where she cannot possibly make the prescribed three paces through the room, and by turning her gaze neither to the mirror nor to the window, either of which would have been acceptable in the context of the poem." 57

Nevertheless, Waterhouse's lady is just as trapped by the entangling threads of the disintegrating tapestry as Hunt's, so she would be likewise incapable of making the described advance to the window. In addition, this way of presentation, as it has already been pointed out, was a feature particular to Hunt's concept and wholly independent from the poem, so Hunt's influence in the case of this particular painting is hardly deniable. It is, however, indeed original that the lady is shown looking up exactly into the spectator's eyes, getting him involved in the action. In this sense, the painting expands on the thought concerned in the poem by extending its discussion of artistic creation with the idea that a painting itself, however realistic, is a necessarily derivative image as compared to the spectator's real world.

This youthful Lady of Shalott is one of Waterhouse's many beautiful female figures combining childish innocence and alluring, irresistible menace like the water nymphs in Hylas and the Nymphs (1896) or his "La Belle Dame Sans Merci." These beautiful femme fatales, or, as Hobson calls them jeune fille fatales, ${ }^{58}$ with their deceptive apparent artlessness are perhaps even more dangerous than the fierce-looking witches of Frederick Sandys, for example, since they catch their victims off their guard. Though a victim herself the Lady becomes a captor, who, looking up into the spectator's eyes in this painting, puts the viewer into a similar captive position as that of the mythological Hylas or Keats's "knight-at-arms" depicted in the other paintings. By presenting Tennyson's Lady as a victim and an enchantress at the same time Waterhouse gives a new dimension to the Lady of Shalott theme.

In 1916, just a year before his death, Waterhouse returned to the legend of the Lady of Shalott once more. This time he went even further back in the story illustrating the lines he also took as his title: "I am Half-Sick of Shadores," said the Lady of Shalott [Fig. 11]. As if the brightly coloured and strongly narrative early Pre-Raphaelite style had been re-discovered this late work has the closest affinities perhaps with Millais' Mariana, since even the depicted mood, the weariness of the

\footnotetext{
${ }^{57}$ Hobson, p. 53.

${ }^{58}$ Hobson, p. 52.
} 
character is alike. The loom, the tapestry, and the beautiful features of the lady are familiar from Waterhouse's previous paintings on the poem, but the image reflected in the mirror: the scenic landscape and the many-towered castle of Camelot appear for the first time. Providing the background of the painting it recalls the similar background views of such late medieval illuminated manuscripts as the famous Book of Hours of the Duke of Berry; however, unlike the castles depicted in these early miniatures, Waterhouse's Camelot is wholly imaginary. In its theme, arrangement, accessories and even colours this late version of The Lady of Shalott is much reminiscent of Waterhouse's Penelope and ber Suitors (1912) painted just a few years earlier. But whereas Penelope is shown being immersed in her work at the loom the Lady of Shalott is depicted in her idleness and the loom at standstill. In her inactivity the Lady is an obvious descendant of the daydreaming, reposing ladies familiar from the canvases of Moore and Leighton. But while his neo-classical colleagues dreamt about the marble palaces and villas of the sunny shores and rich meadows of Greece and Italy and set their maidens into an idealised ancient world, Waterhouse conceived a less exotic land and put his figure into a medieval context.

Christopher Wood describes the work of Waterhouse as "an enchanted garden," if it were reality itself. And Waterhouse's "enchanted garden" is just as wished for today as it was a hundred years ago. His first The Lady of Shalott is said to be one of the most popular pictures of the Tate Gallery selling more postcards a year than any other. ${ }^{60}$ But Waterhouse's contemporaries were likewise captivated by his visionary world. As an article published in The Studio in September 1908 wrote:

[Waterhouse] lives in a world of his own imaging, a world which knows nothing of the stress and turmoil of modern life, and in which the dominant note is a kind of gentle melancholy without bitterness and without sentimentality. [...] In his art there is a restfulness which is peculiarly satisfying, a delicate reticence which comes as a real relief from the strenuousness of the times in which we live; and there is, too, a romantic grace which is not artificial or obviously invented, but really the outcome of the artist's own aestheticism. ${ }^{61}$

\footnotetext{
${ }^{59}$ Wood. The Pre-Raphaelites, p. 148.

${ }^{60}$ Wood. Victorian Painting, p. 238.

${ }^{61}$ "Some Drawings by J. W. Waterhouse, RA." The Studio 186 (1908) 246-252, p. 250.
} 


\subsubsection{Meteyard's dream vision}

Another unreal world, but a less enchanting one, appears in Meteyard's painting on Tennyson's poem, which bears the same title and depicts the same scene as Waterhouse's last picture on the theme [Fig. 12]. Meteyard was one of the late followers of Pre-Raphaelitism and belonged to what is called the "Birmingham Group." The group had close associations with the Arts and Crafts movement, Meteyard himself is noted for his craftsmanship in enamelling, stained glass and leatherwork. The most important inspiration to the group came from the Birmingham-born Burne-Jones, who, as the President of the Birmingham Society of Artists, where Meteyard was secretary, had a personal connection with the members and had a direct influence on their art. Meteyard's work in general is often viewed in its relation to Burne-Jones, the latter's biographers, Harrison and Waters finding it "much reminiscent of Burne-Jones in colour, imagery, and atmosphere, yet [...] more corporeal and less languorous, and [in the] interpretations of the themes [...] quite different." ${ }^{, 62}$

In the spellbound world of Meteyard's "I am Half-Sick of Shadowes" said the Lady of Shalott (1913) the lady's chamber seems to be literally the realm of shadows, as no natural light is shown to enter it. The mirror reflects only the darkness of the night with the dim, moonlit figures of the lovers mentioned in the poem, and the whole painting is dominated by the colour-harmony of the dark, leaden hues of blue, grey and purple. Like these, the lady's closed eyes as well may also suggest an unrealistic, shadowy life. The sweet smell of the host of peonies in the foreground seems to overpower the lady, who is shown leaning back in her chair faintly, almost lifeless. According to the language of flowers the peony stands for bashfulness, ${ }^{63}$ and here it may refer to the enclosed world the lady is confined to live in.

What makes Meteyard's presentation of The Lady of Shalott unique is that it unites the Tennysonian theme with the late 19th-century concern with sleep. The Lady's closed eyes, the darkness of the night, and the overpowering smell of the flowers all refer to it. The concept of the painting may have been inspired by such works of Burne-Jones as the "Briar Rose Series," and his monumental last piece The Last Sleep of Arthur in Avalon (1881-98), which display the master's strong fascination with sleep. To Burne-Jones sleep meant a world of dream

\footnotetext{
${ }^{62}$ Martin Harrison \& Bill Waters. Burne-Jones. London: Barrie and Jenkins, 1989, p. 183.

${ }^{63}$ Cf. Sheila Pickles. The Language of Flowers. New York: Harmony Books, 1989, p. 77.
} 
vision, it meant isolation and independence from the worldly matters of everyday reality. In connection with the story of Tennyson's The Lady of Shalott all this bears relevance, since the Lady's shadowy world of reflection is as detached from reality as a dream. In addition, sleep is often regarded as a suspended state between life and death, thus Meteyard's pictorial reference to sleep can also be seen as an indication of the curse and the Lady's impending death.

Besides Burne-Jones, however, Leighton was also known of his sleeping figures, and in her corporeality and sensuality Meteyard's Lady is definitely closer to the sleeping girls of Leighton's Summer Moon, Flaming June or The Garden of the Hesperides than to the ethereal, graceful figures of Burne-Jones. Richard Ormond's description of Summer Moon is surprisingly appropriate to Meteyard's work:

Leighton's monumental women are latent with power and significance. [...] The subject is suffused with poetry and mystery, and the figures appear suspended between life and death. [...] Through their beauty and sensuousness the women stand for the powers of nature under whose spell they lie enchanted. ${ }^{64}$

It is interesting to see that whereas the early Pre-Raphaelite painters were mostly fascinated by the dramatic moments of the story of the Lady of Shalott, their late successors showed such a decisive preference for subjects of a dreamy, melancholic, and inactive character. The Aesthetic Movement, and, as a part of it, the Classical Revival of the 1860s, which brought the popularity of works presenting "a harmonious, luxurious ideal of beauty in repose," 65 had an influence even on such quasi-medieval subjects as Tennyson's The Lady of Shalott. In addition, Meteyard's reliance on colour-harmony is also akin to the same pursuit of the aesthetic painters. Whistler, for example, was famous for his 'musical' compositions in which he based his work on the use of the varying shades of just one dominant colour. Some of Rossetti's work like A Woman in Yellow (1863) or Veronica Veronese (1872) show similar concerns, and the ashy, funeral colours of Meteyard's painting have an obvious predecessor in the "Tartarean grey" version of Proserpine. Aesthetic considerations being dominant, there is nothing in Meteyard's painting to suggest the medieval origin of the subject; the story of the lady of Shalott seems to live on completely independent from it.

\footnotetext{
64 Richard Ormond. "Leighton and his Contemporaries." Frederick, Lord Leighton: Eminent Victorian Artist. London: Royal Academy of Arts \& Abrams, 1996, 21-40, pp. 34-35.

${ }^{65}$ Julian Treuherz. Victorian Painting. London: Thames and Hudson, 1993, p. 136.

${ }^{66}$ The expression is used by Rossetti himself in his poem "Proserpine."
} 
By the end of the 19th century in most of the paintings the historical aspect of Tennyson's "passion for the past" reflected in the poem had been overshadowed by its mysterious and poetic qualities. What Henry James wrote about Burne-Jones' art in 1877 seems to apply to most of the late Pre-Raphaelite works, according to which their art was "the art of culture, of reflection, of intellectual luxury, of aesthetic refinement, of people who look at the world and at life not directly, as it were, and in all its accidental reality, but in the reflection and ornamental portrait of it furnished by literature, by poetry, by history, by erudition." ${ }^{67}$ In the early 20th century the legendary world Tennyson reproduced in his poems provided for artists a welcome retreat from the harsh and brutal reality of their contemporary world.

\section{CONCLUSION}

Bearing in mind that Hunt's minutely detailed oil painting on Tennyson' The Lady of Shalott, which is loaded with symbols of moral significance, is almost contemporary with Meteyard's aesthetic conception one may say that in general the theme - the choice of the depicted incident - and the style - the way of execution - can depend as much on the artist's personal conviction as on the time of production. Nevertheless, the analysis of the Pre-Raphaelite renditions of Tennyson's poem show that a line of development, a movement from midVictorian narrativity to late-Victorian aestheticism can clearly be established. Accordingly, re-interpreting their literary source the early works were aiming at re-creating the story and the message of the written text. At the same time the dominance of such a definite and didactic purpose led to the destruction of the poem's mysterious, balladistic character. Later, however, with the spread of a new artistic ideology inspired by the writings of Whistler and Walter Pater, that challenged the moralistic theories of Ruskin, the emphasis gradually shifted to a wish to capture rather the melancholic beauty and the emotional atmosphere of the poem. And though it meant a break with its historical and literal context, it brought the successful rendition of the poem's magic spell and sentiment.

As literary essays these paintings show different approaches, and find different answers. And as the striking dissimilarity of Hunt's early drawing and Meteyard's painting show depending on the chosen point of view one may come to surprisingly diverse conclusions.

\footnotetext{
${ }^{67}$ In Wood. The Pre-Raphaelites, p. 95.
} 


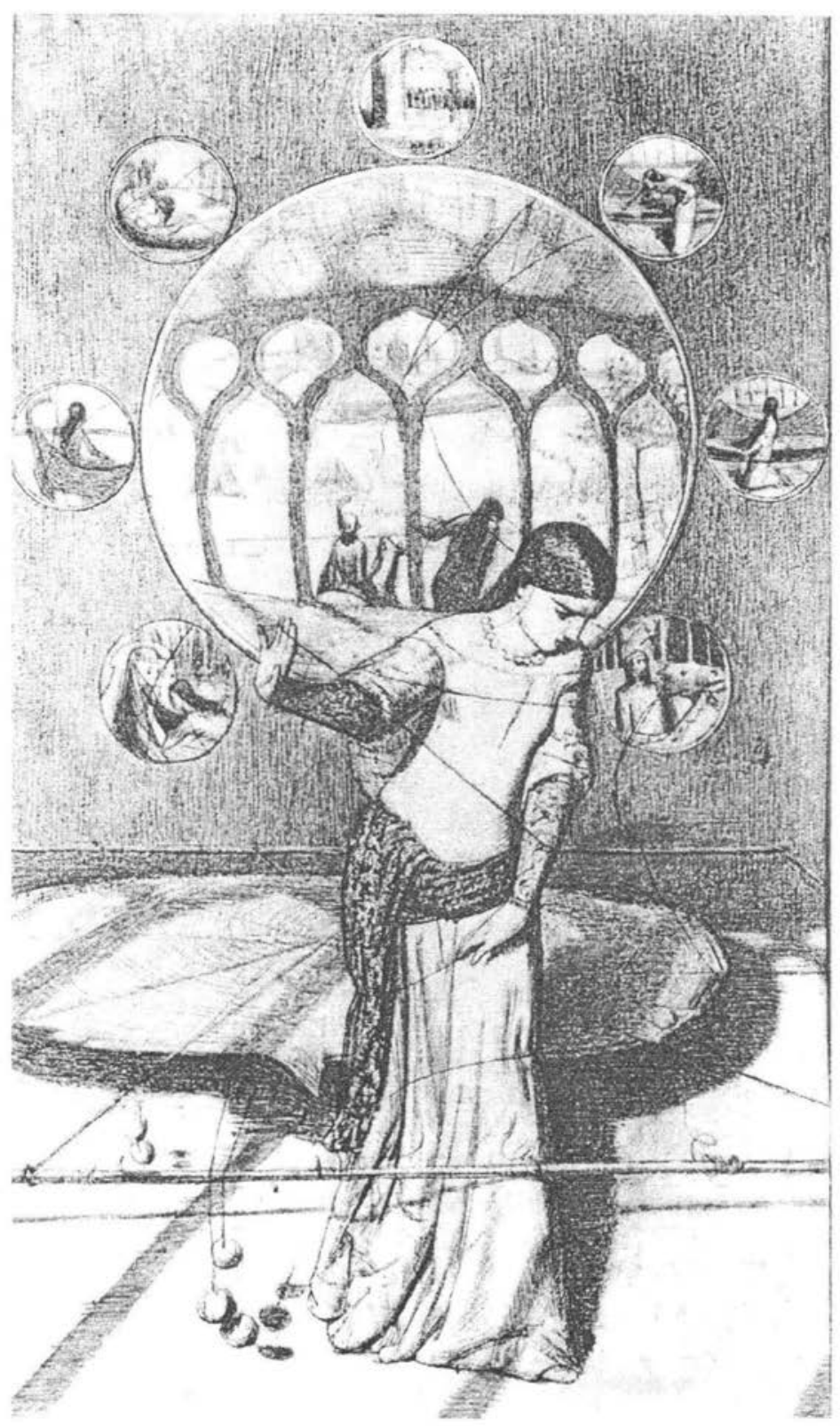

FIGURE 1. William Holman Hunt: The Lady of Shalott (1850) 


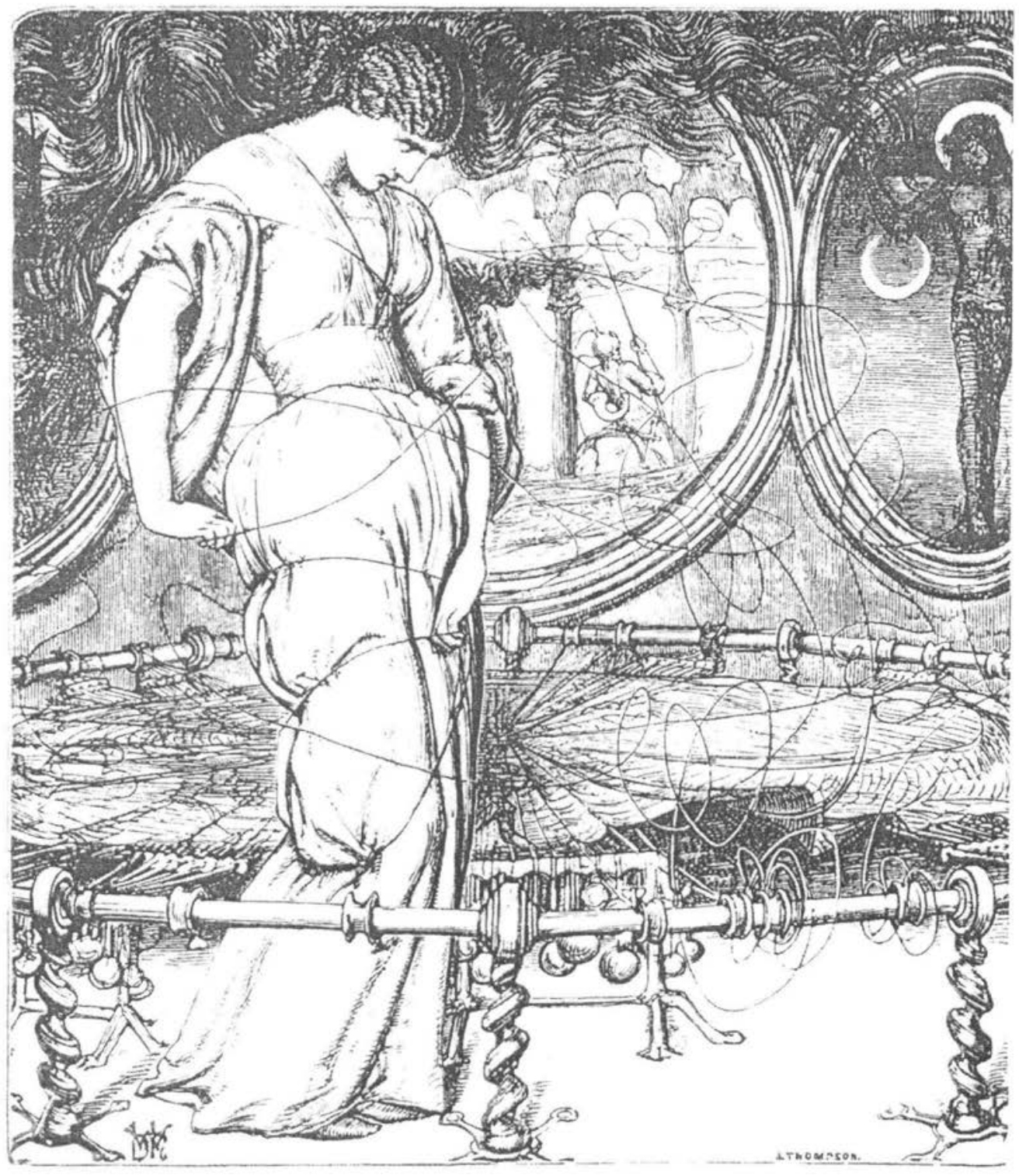

FIGURE 2. William Holman Hunt: The Lady of Shalott (1857) 


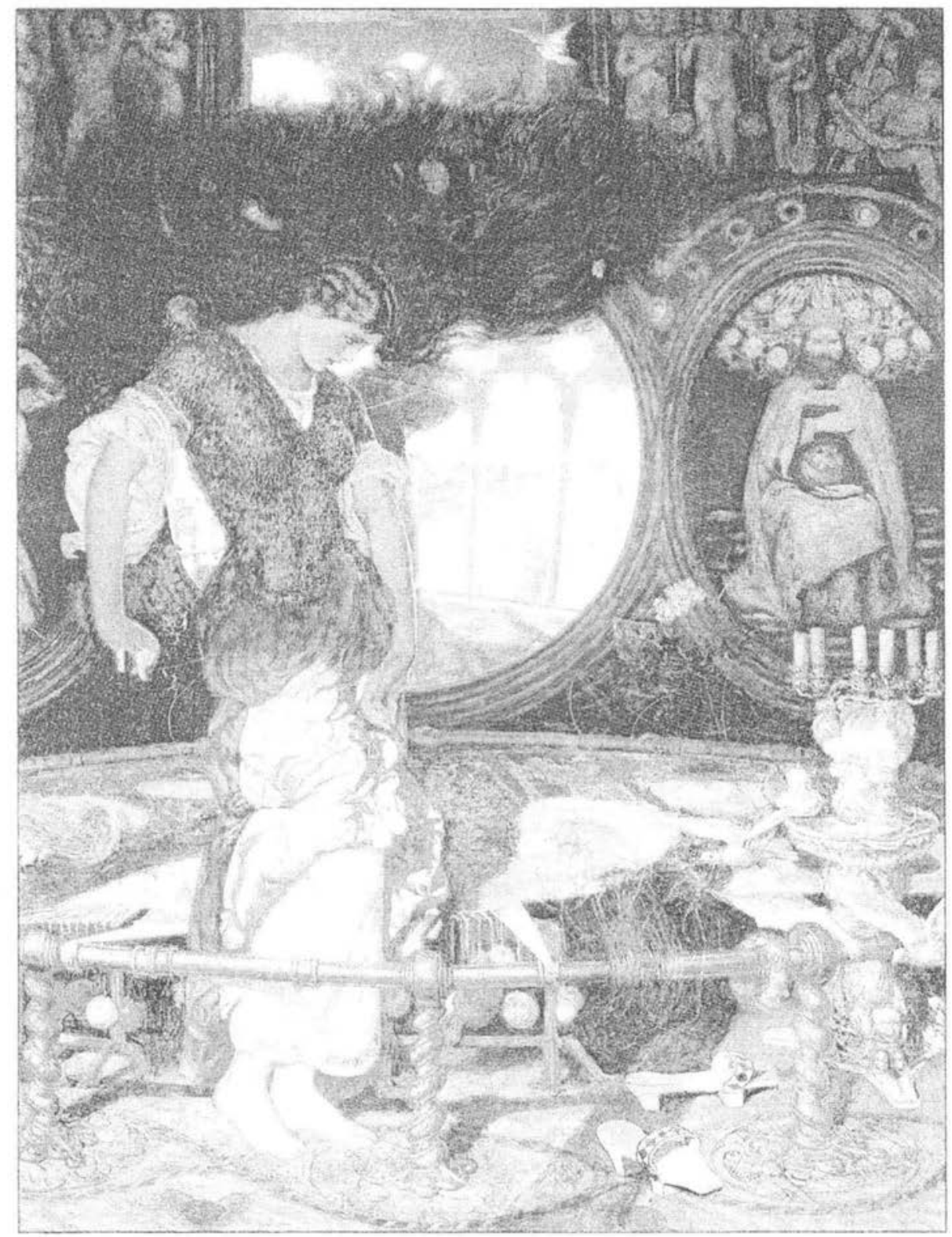

FIgURE 3. William Holman Hunt: The Lady of Shalott (1889-92) 


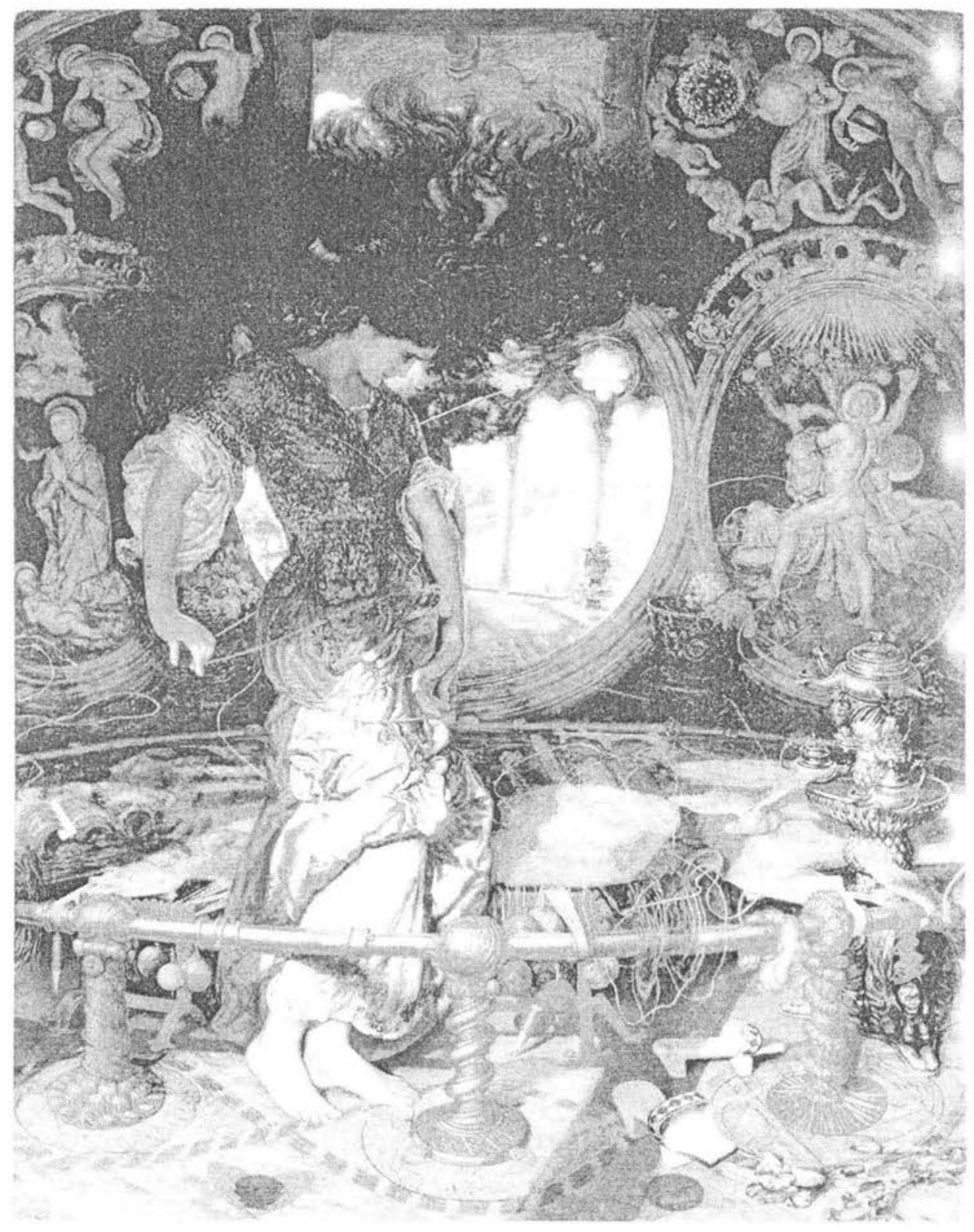

FIGURE 4. William Holman Hunt: The Lady of Shalott (1886-1905) 


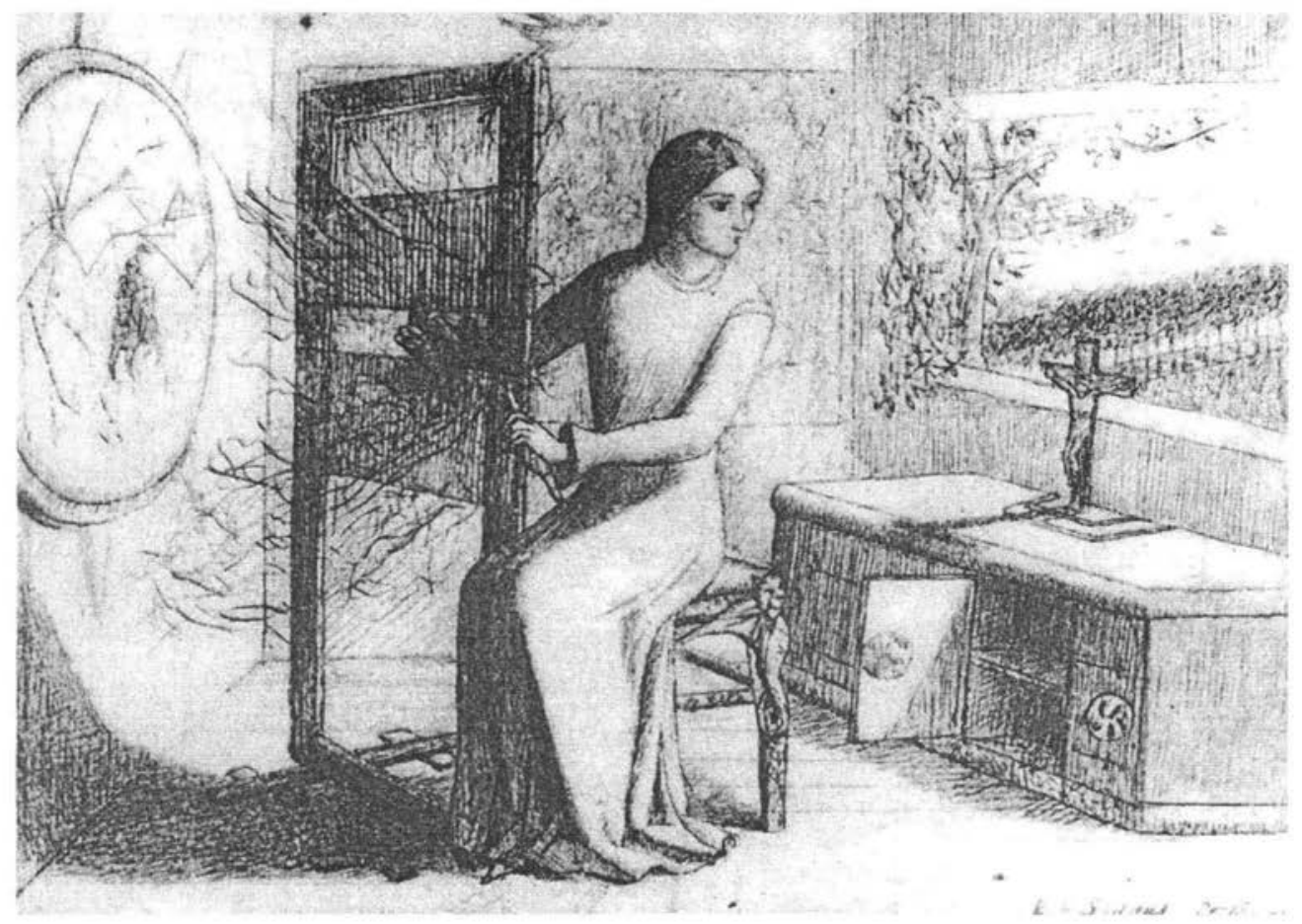

FIGURE 5. Elizabeth Siddal: The Lady of Shalott 


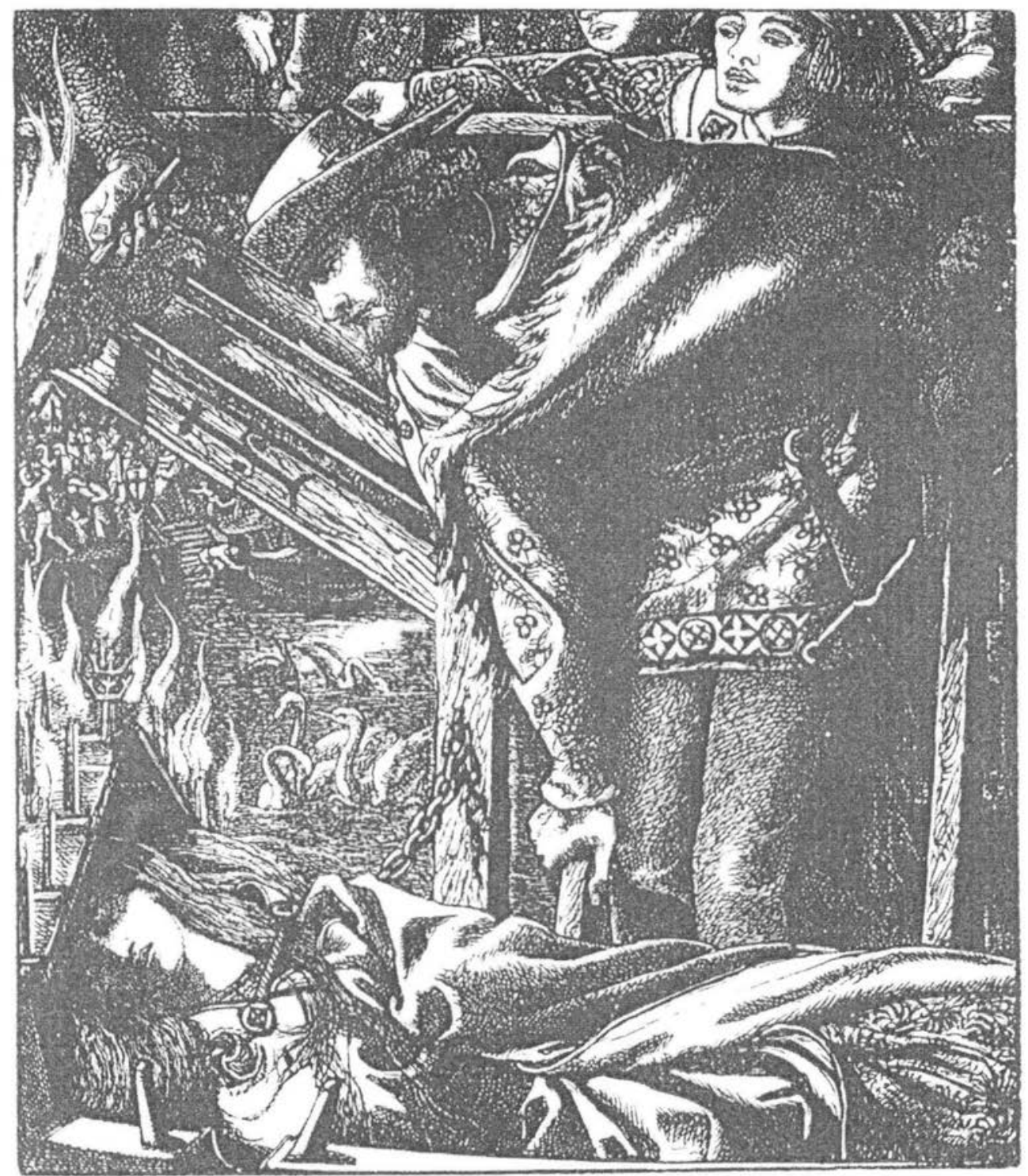

FIGURE 6. Dante Gabriel Rossetti: The Lady of Shalott 


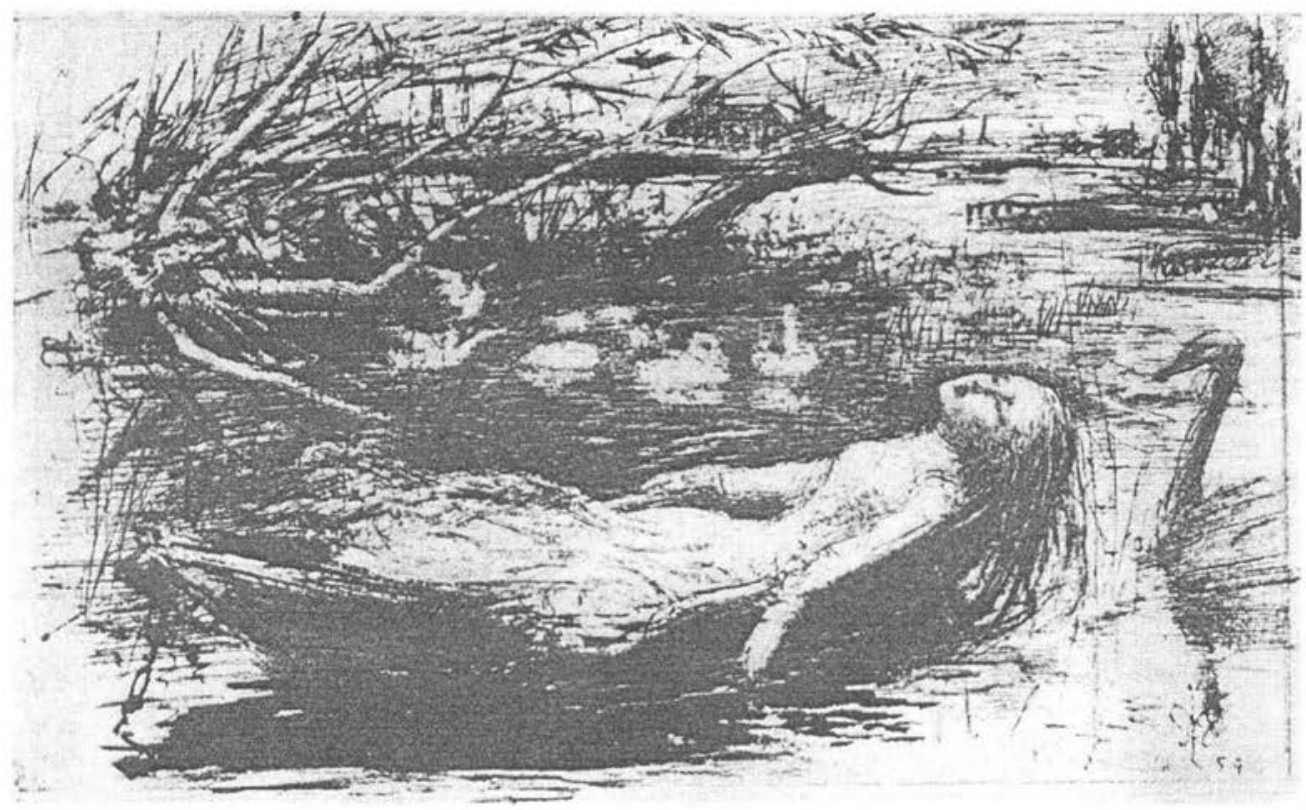

FIGURE 7. John Everett Millais: The Lady of Shalott 


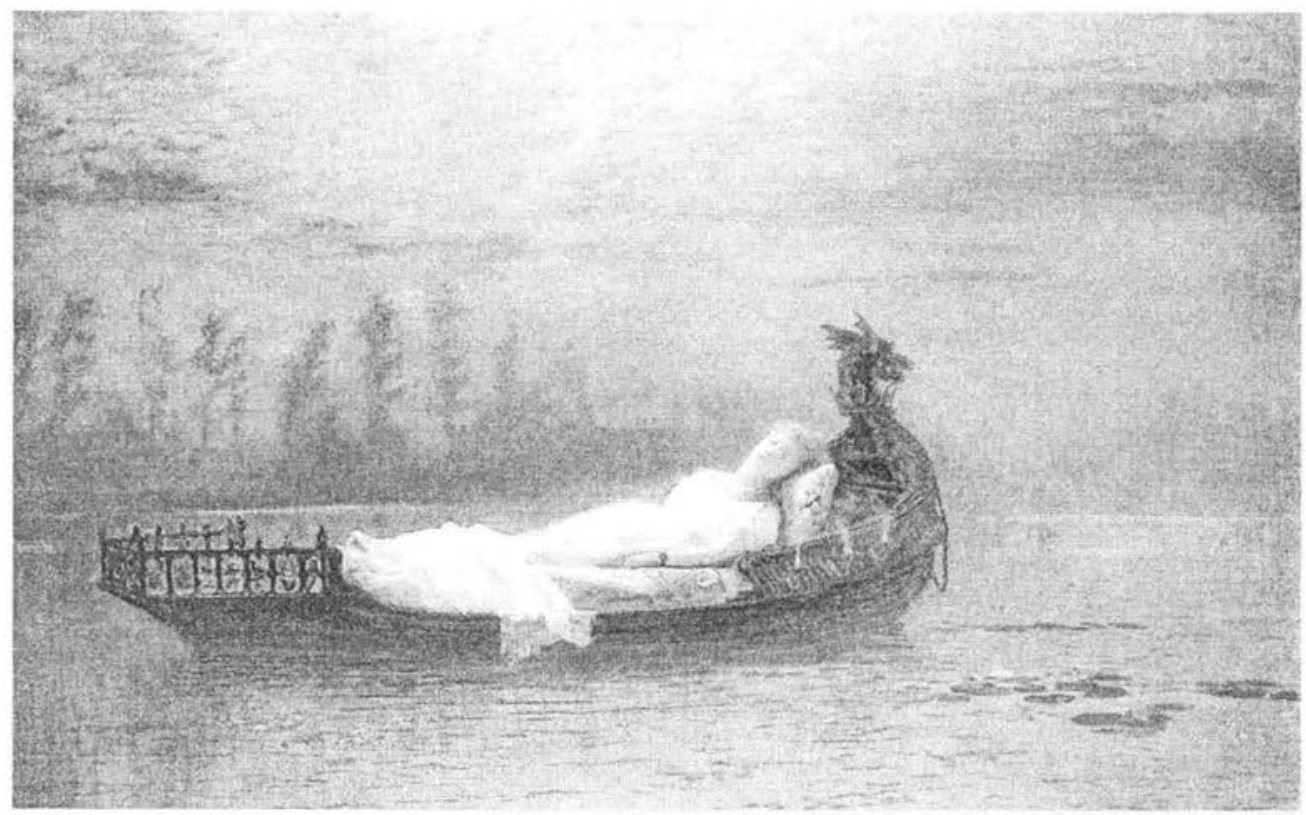

FIGURE 8. John Atkinson Grimshaw: The Lady of Shalott 


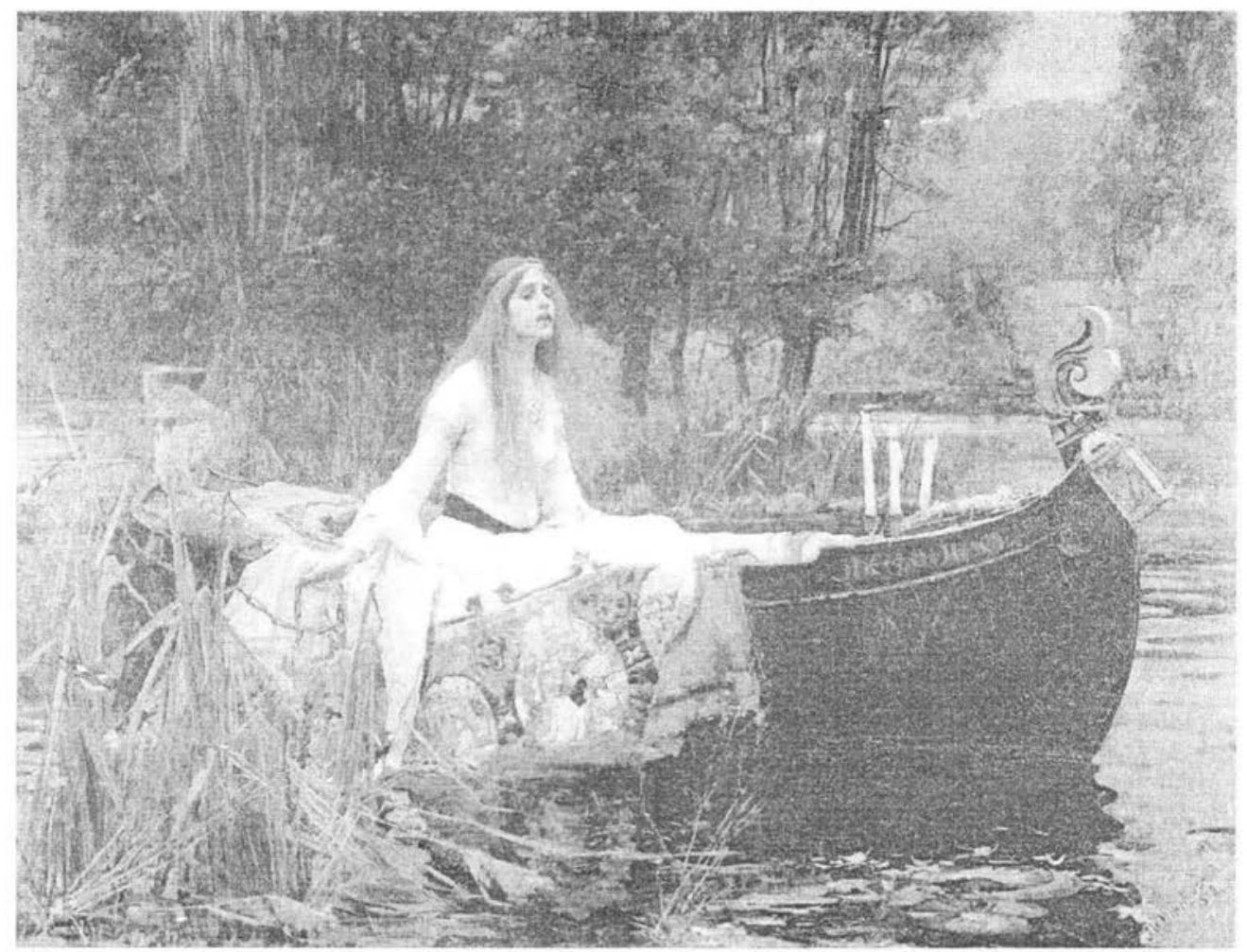

FIGURE 9. John William Waterhouse: The Lady of Shalott (1888) 


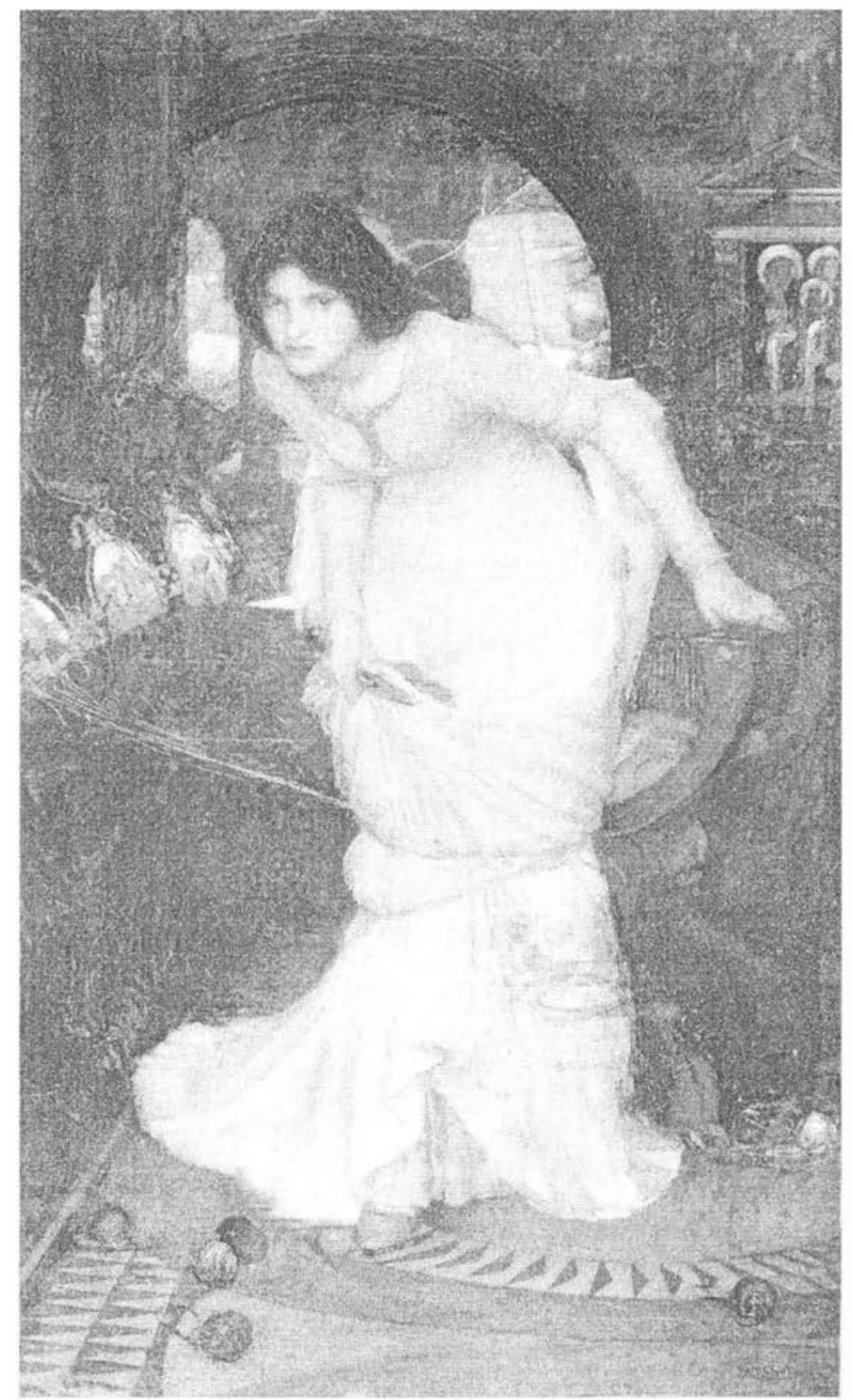

FIGURE 10. John William Waterhouse: The Lady of Shalott (1894) 


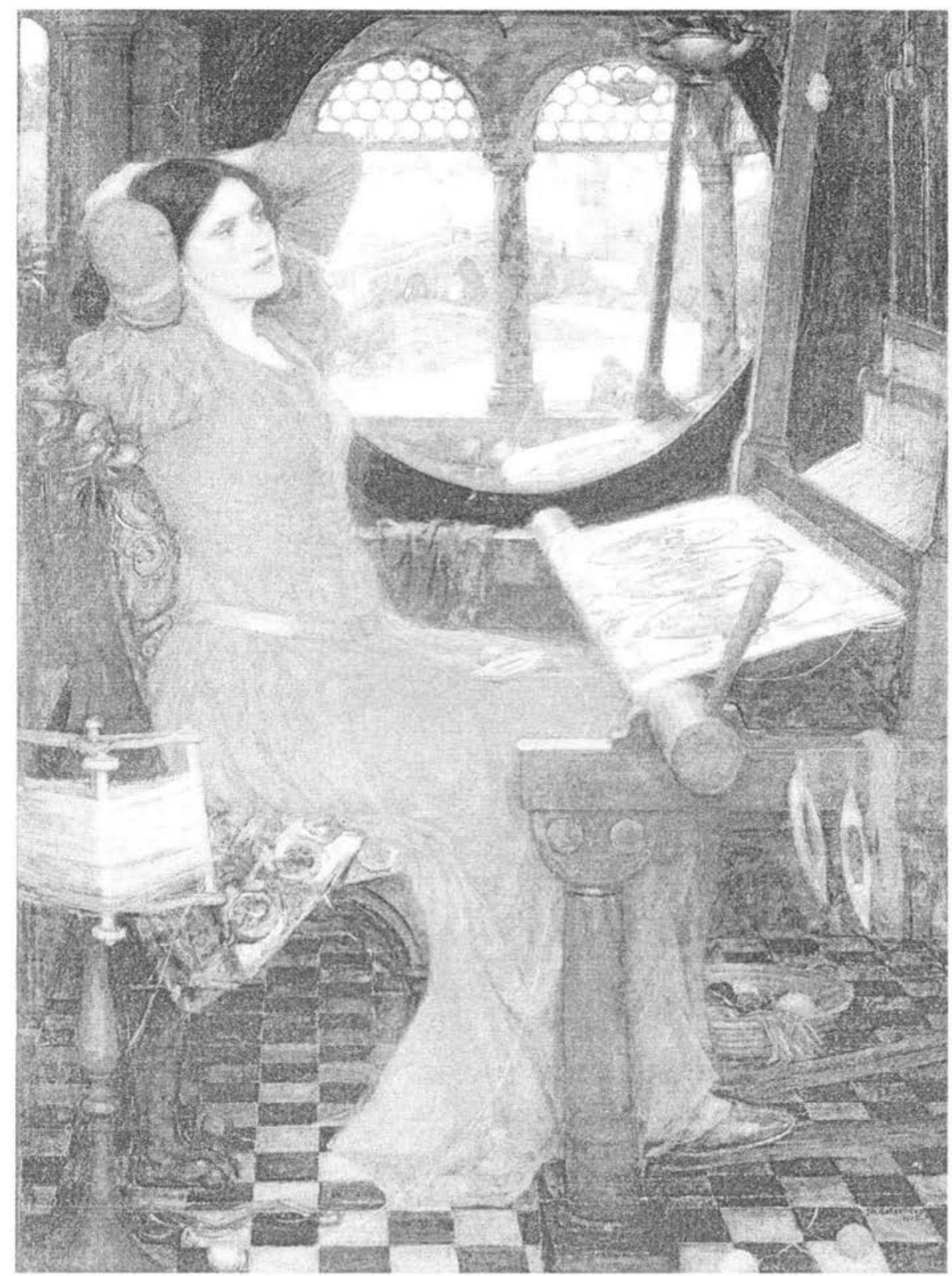

FIGURE 11. J. W. Waterhouse: 'I am half-sick of shadows,' said the Lady of Shalott 


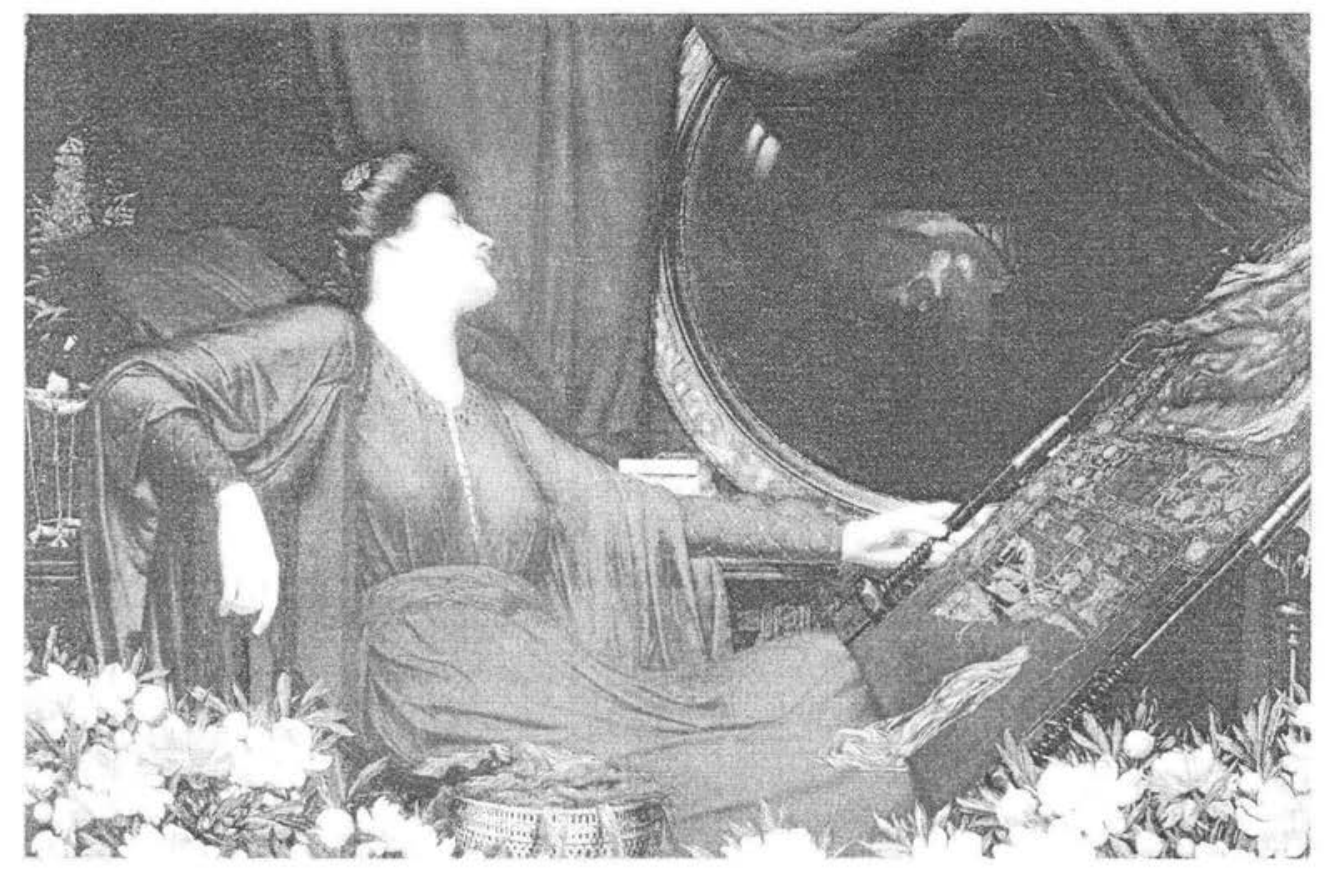

FIGURE 12. H. S. Meteyard: 'I am half-sick of shadows,' said the Lady of Shalott 